\title{
Deep-water polychaetes (Annelida) from the southeastern Gulf of California, Mexico
}

\author{
Nuria Méndez \\ Unidad Académica Mazatlán. Instituto de Ciencias del Mar y Limnología, UNAM. P.O. Box 811, Mazatlán 82000, \\ Sinaloa, México. Fax: +52(69)826133; nuri@ola.icmyl.unam.mx
}

Received 20-I-2002. Corrected 02-II-2005. Accepted 17-III-2006.

\begin{abstract}
Polychaetes inhabiting deep-sea soft bottoms from the southeastern Gulf of California were collected during four oceanographic cruises during 2000 and 2001. Sampling of benthic organisms was performed with a benthic sledge to collect epifauna and a Karling dredge for epifauna and infauna, in a depth range from 732 to 2 $250 \mathrm{~m}$. A list of the polychaetes that were collected and their distribution are presented here. A total of 73 species (distributed among 33 families) were identified. Moreover, 11 species were identified only to genus level and 20 species only to family level. With the exception of Ancistrosyllis hartmanae and Melinnampharete eoa, all identified species have been previously reported in soft bottoms of the Gulf of California or in adjacent areas. Additional previously unreported information is provided herein regarding depth ranges, geographical distribution, morphology and tubes inhabited by the organisms. The morphology of the ampharetids Amage sp. and Samytha sp. does not coincide with that of other species in these genera reported for the Gulf of California, which suggests that they are probably undescribed species. Rev. Biol. Trop. 54 (3): 773-785. Epub 2006 Sept. 29.
\end{abstract}

Key words: Polychaeta, deep-sea, tubes of polychaetes, bathymetric distribution, southeastern Gulf of California, Mexico.

The southern Gulf of California meets the Pacific Ocean at depths greater than $3000 \mathrm{~m}$, while the northern part is relatively shallow (Parker 1964, Alvarez-Borrego and Schwartzlose 1979). Dissolved oxygen level is one of the major limiting factors affecting the presence of benthic and demersal species, as with most marine invertebrates which are affected by extremely low oxygen concentrations (Rosenberg et al. 1991, Diaz and Rosenberg 1995).

Numerous studies on the polychaetes inhabiting the continental shelf of southern California have been conducted (ie. Hartman 1938, 1939a,b, 1944a,b,c, 1951, 1955, 1961, 1966, 1968, 1969, Fauchald 1968, 1970, Kudenov 1975a,b, 1980, Williams 1987, among others). Polychaetes from the Gulf of California continental shelf have been studied by Sarti-Martínez (1984), Lezcano-Bustamante (1989), Hernández-Alcántara (1992) and Hernández-Alcántara and Solís-Weiss (1999). Literature of other studies in the area is included in Salazar-Vallejo et al. (1989). Nevertheless, polychaetes from deep-sea waters in the Gulf of California and adjacent areas have been hardly investigated. The first studies of the polychaetes from deep basins off southern California were by Hartman (1960, 1963). Fauchald (1972) later identified 227 species (of which 66 were new) from material collected during the ALBATROSS expedition as reported by Chamberlin (1919a) and Treadwell (1923), and from material collected during two cruises with the VELERO IV in 1967 and 1970. The most recent studies in the hydrothermal vents from the Guaymas basin were reported by Blake (1985), Solís-Weiss and 
Hilbig (1992) and Solís-Weiss and HernándezAlcántara (1994). Other recent studies concerning deep-sea polychaetes in the northern Pacific were performed by Fauchald and Hanckock (1981) in Central Oregon, and Blake and Hilbig (1990) in the Juan de Fuca and the Explorer Ridge systems in the northeast Pacific. Recently, Blake and other collaborators (1994-2000) compiled information related to polychaetes from the Point Conception region of southern California at depths from 50 to $1000 \mathrm{~m}$, which includes four volumes of a Taxonomic Atlas of the benthic fauna of the Santa Maria Basin and Western Santa Barbara Channel.

The TALUD project, organized by the Laboratory of Invertebrates of the Mazatlán Marine Station (Instituto de Ciencias del Mar y Limnología, UNAM), is a multidisciplinary project encompassing the study of crustaceans, mollusks, polychaetes, fish and meiofauna in the southern Gulf of California. Prospective cruises were conducted in 1989-1991 (TALUD 1 to 3) wherein no grabs were used and the polychaete fauna was not studied. Four additional cruises (TALUD 4 to 7) were organized in 2000 and 2001, which did include the collection of polychaetes.

During the last decade, few studies of polychaetes inhabiting deep-water have been performed in southern California or the Gulf of California. The purpose of this paper is to contribute to the knowledge of the polychaete fauna occurring offshore in soft sediments at a depth range from 732 to $2250 \mathrm{~m}$ in the Southeastern Gulf of California.

\section{MATERIALS AND METHODS}

Benthic organisms associated with deep soft bottoms (732 to $2250 \mathrm{~m}$ depth) were collected aboard the R/V "El Puma" (Universidad Nacional Autónoma de México) during four oceanographic cruises: TALUD 4 in August 2000 (11 stations), TALUD 5 during December 2000 (ten stations), TALUD 6 in March 2001 (12 stations), and TALUD 7 in June 2001 (13 stations). Two types of gear were used at most stations: a) a $2.35 \mathrm{~m}$ wide by $0.95 \mathrm{~m}$ high modified benthic sledge equipped with a collecting net of ca. $5.5 \mathrm{~cm}(21 / 4$ ") stretch mesh lined with ca. $2 \mathrm{~cm}(3 / 4 ")$ mesh net in the mouth area, and b) a 110x40x14 cm Karling dredge used to collect sediments to a depth of $7 \mathrm{~cm}$, with a capacity of 851 .

Polychaetes retained in the benthic sledge were directly collected with forceps and fixed with $10 \%$ formaldehyde solution. The sediment collected with the Karling dredge was washed through a $0.5 \mathrm{~mm}$ sieve and the polychaetes were sorted and fixed on board. Specimens found inside thick muddy tubes were fixed by adding $10 \%$ formaldehyde solution through one of the tube openings using a syringe.

In the laboratory, polychaetes were washed and preserved in $70 \%$ ethanol and identified to the specific level, as possible, following the keys of Chamberlin (1919b), Hartman (1944a, 1957, 1960, 1968, 1969), Pettibone (1966), Fauchald (1968, 1970, 1972, 1977), Fauchald and Hancock (1981), Paxton (1986), HernándezAlcántara (1992) and Petersen (2000).

\section{RESULTS}

The position and depth range of stations in which polychaetes were collected are included in Table 1.

A total of 73 species, representing 33 families, were identified. Additional specimens belonging to the genera Polydora, Cirratulus, Tharyx, Notomastus, Eumida, Sthenolepis, Sigambra, Pareurythoe (?), Amage, Samytha and Thelepus were not identified to species due to their poor condition. Important taxonomic structures from several specimens from the families Spionidae, Maldanidae, Opheliidae, Phyllodocidae, Nereididae, Glyceridae, Lumbrineridae, Ampharetidae, Sabellidae and Serpulidae were absent, making further identification impossible. They were catalogued as "indeterminable" (Table 2).

The families best represented in the study area are Ampharetidae (13 taxa), Maldanidae 
TABLE 1

Position and sampling depth range of the stations where polychaetes were collected

\begin{tabular}{|c|c|c|c|c|c|c|}
\hline \multirow[b]{2}{*}{ Station } & \multirow[b]{2}{*}{ Latitude } & \multirow[b]{2}{*}{ Longitude } & \multicolumn{4}{|c|}{ Depth range $(\mathrm{m})$} \\
\hline & & & TALUD 4 & TALUD 5 & TALUD 6 & TALUD 7 \\
\hline 3 & 2200.2 & 10628.1 & - & 732 & $770-780$ & $740-750$ \\
\hline 4 & 2204.6 & 10634.7 & - & - & $1190-1250$ & $1200-1230$ \\
\hline 5 & 2200.7 & 10639.9 & - & $1515-1620$ & $1470-1530$ & - \\
\hline 6 & 2200.0 & 10648.1 & - & $1950-2010$ & - & - \\
\hline 11 & 2315.0 & 10659.0 & - & $850-870$ & $825-855$ & $780-790$ \\
\hline 12 & $23 \quad 18.6$ & 10726.9 & - & $1160-1170$ & - & $1040-1120$ \\
\hline $13 b$ & 2330.3 & 10744.0 & - & - & - & $1400-1450$ \\
\hline 14 & $23 \quad 16.3$ & 10740.7 & $2220-2250$ & $2080-2140$ & - & - \\
\hline 18 & 2415.0 & 10817.1 & $908-944$ & $940-990$ & $890-950$ & $950-1010$ \\
\hline 19 & 2416.4 & 10824.3 & $1196-1200$ & $1180-1200$ & $1160-1200$ & $1160-1180$ \\
\hline 20 & 2414.8 & 10835.2 & $1500-2000$ & - & $1250-1440$ & - \\
\hline 25 & 2451.7 & 10857.9 & $778-800$ & $800-860$ & $830-850$ & $780-850$ \\
\hline 26 & 2456.3 & 10911.8 & $1200-1274$ & $1280-1310$ & $1190-1270$ & $1180-1220$ \\
\hline 27 & 2501.2 & 10911.1 & - & - & $1580-1600$ & $1580-1600$ \\
\hline 28 & 2452.6 & 10937.7 & $2024-2040$ & - & - & - \\
\hline $32 b$ & 2603.0 & 10955.4 & - & - & - & $850-880$ \\
\hline 33 & 2545.8 & 10948.7 & $1060-1090$ & - & - & - \\
\hline $33 b$ & 2606.5 & 11006.7 & - & - & - & $1260-1300$ \\
\hline 34 & 2543.8 & 10954.0 & 1244 & - & $1240-1270$ & \\
\hline $34 b$ & 2605.5 & 11010.5 & - & - & - & $1500-1520$ \\
\hline 35 & 2557.8 & 11011.4 & $2000-2100$ & - & - & - \\
\hline
\end{tabular}

(11 taxa), and Cirratulidae and Phyllodocidae (eight taxa each). Based on their occurrence for different stations and cruises, the most representative species for the study area are: Melinna exilia, Melinnampharete eoa, Thelepus hamatus, Mexamage corrugata, Terebellides stroemi, Fauveliopsis rugosa, Nothria iridiscens, Califia calida, Neoheteromastus lineus and Maldane cristata. Except for Ancistrosyllis hartmanae and $M$. eoa, all identified species have been previously reported for the Gulf of California or adjacent areas in soft bottoms.

Comparing the two sampling methods, higher numbers of taxa were collected with the Karling dredge during the four cruises: TALUD
4, 44 taxa (Karling) vs. 25 taxa (benthic sledge); TALUD 5, 28 taxa vs. 17; TALUD 6, 42 taxa vs. 20; TALUD 7, 50 taxa vs. 19.

Only species for which new information was obtained were treated individually. New data related to depth range, distribution, morphology or tube description (or other protective structures in which the animals were found) are provided here.

\section{Family Chaetopteridae}

Phyllochaetopterus limicolus. This species lives in a slender, smooth, cylindrical, unbranched tube measuring $20 \mathrm{~cm}$ long by $0.5-0.6 \mathrm{~cm}$ wide 
TABLE 2

List of polychaete species collected during the four cruises

$\begin{array}{llll}\text { TALUD } 4 & \text { TALUD } 5 & \text { TALUD } 6 & \text { TALUD } 7\end{array}$

SPECIES

KD $\quad$ BS $\quad$ KD $\quad$ BS

KD BS

KD

BS

Orbiniidae

Califia calida Hartman, 1957

Haploscoloplos elongatus (Johnson, 1901)

Phylo nudus (Moore, 1911)

\section{Paraonidae}

Aedicira alisetosa Fauchald, 1972

Aedicira longicirrata Fauchald, 1972

Paraonis pycnobranchiata Fauchald, 1972

\section{Spionidae}

Polydora sp.

Prionospio (A.) vermillionensis Fauchald, 1972

Spiophanes fimbriata Moore, 1923

\section{Poecilochaetidae}

Poecilochaetus johnsoni Hartman, 1939

\section{Heterospionidae}

Heterospio catalinensis (Hartman, 1944)

\section{Chaetopteridae}

Phyllochaetopterus limicolus Hartman, 1960

\section{Cirratulidae}

Aphelochaeta monilaris Hartman, 1960

20,26

Chaetozone corona Berkeley \& Berkeley, 1941

19

Chaetozone setosa Malmgren, 1867

Cirratulus sinincolens Chamberlin, 1919

Cirratulus cf sinincolens Chamberlin, 1919

Cirratulus sp.

26

Tharyx multifilis Moore, 1909

Tharyx tesselata Hartman, 1960 
TABLE 2 (...continued)

List of polychaete species collected during the four cruises

$\begin{array}{llll}\text { TALUD } 4 & \text { TALUD } 5 & \text { TALUD } 6 & \text { TALUD } 7\end{array}$

SPECIES

KD

BS

$\mathrm{KD}$

BS

KD

BS

KD

BS

Notomastus $\mathrm{sp}$.

28

\section{Maldanidae}

Asychis ramosus Levenstein, 1961

20

Maldane cristata Treadwell, 1923

Maldanidae sp. 1

18

33

$14 \quad 18$

18,25

$13 b$

Maldanidae sp. 2

34

34

26

28

35

6

27

$13 b$

Maldanidae sp. 3

19

20

Maldanidae sp. 4

20,33

19

5,27

34

Maldanidae sp. 6

Maldanidae sp. 7

Maldanidae sp. 8

Maldanidae indeterminable

$5,18,25 \quad 25$

$5,19,20$

25

$$
4,34 b
$$

\section{Opheliidae}

Ammotrypane pallida Hartman, 1960

14

Opheliidae indeterminable

Phyllodocidae

Eteone cf dilatae Hartman, 1936

Eulalia anoculata Fauchald, 1972

Eulalia strigata Hartman, 1968

Eumida sanguinea (Oersted, 1843)

Eumida sp.

Steggoa gracilior Chamberlin, 1919

34

Phyllodocidae indeterminable

\section{Aphroditidae}

Aphrodita parva Moore, 1905

Laetmonice pellucida Moore, 1903

\section{Polynoidae}

Halosydna johnsoni (Darboux, 1899)

4, 19 
TABLE 2 (...continued)

List of polychaete species collected during the four cruises

$\begin{array}{llll}\text { TALUD } 4 & \text { TALUD } 5 & \text { TALUD } 6 & \text { TALUD } 7\end{array}$

SPECIES

Polynoidae sp. 1

Polynoidae sp. 2

Polynoidae sp. 3

\section{Sigalionidae}

Leanira alba Moore, 1910

Sthenolepis sp.

\section{Pilargidae}

Ancistrosyllis hartmanae Pettibone, 1966

Sigambra sp.

Syllidae

Exogone lourei Berkeley \& Berkeley, 1938

\section{Nereididae}

Ceratocephale loveni pacifica Hartman, 1960

Ceratonereis vermillionensis Fauchald, 1972

Nereis anoculopsis Fauchald, 1972

Nereididae indeterminable

\section{Glyceridae}

Glyceridae indeterminable

$\mathrm{KD}$

BS

25

19

\section{Goniadidae}

Goniada brunnea Treadwell, 1906

Nephtyidae

Nephtys paradoxa Malm, 1874

\section{Amphinomidae}

Pareurythoe (?) sp.

Pseudeurythoe ambigua (Monro, 1933)

\section{Onuphidae}

Anchinothria fissurata Fauchald, 1972

Nothria abyssalis Fauchald, 1968

Nothria iridescens (Johnson, 1901)

Onuphis profundi Fauchald, 1968

Eunicidae

Eunice megabranchia Fauchald, 1970
20,28

3

19, 26, 27
26,33

33

33

19
25

20

25

14
$33 b$

12

KD 
TABLE 2 (...continued)

List of polychaete species collected during the four cruises

$\begin{array}{llll}\text { TALUD } 4 & \text { TALUD } 5 & \text { TALUD } 6 & \text { TALUD } 7\end{array}$

SPECIES

KD BS KD BS

KD BS

KD

BS

\section{Lumbrineridae}

Lumbrineris bicirrata Treadwell, 1929

$19,27,33 b$

Lumbrineris cedroensis Fauchal, 1970

Ninoe foliosa Fauchald, 1972

Ninoe fuscoides Fauchald, 1972

Ninoe longibranchia Fauchald, 1972

Lumbrineridae indeterminable

\section{Arabellidae}

Drilonereis falcata Moore, 1911

$32 b, 33 b$

25

$3 \quad 3$

\section{Sternaspidae}

Sternaspis fossor Stimpson, 1854

19,26

25

18

20,34

$19,33 \mathrm{~b}$

\section{Flabelligeridae}

Brada pluribranchiata (Moore, 1923)

$18,25,33$

$3 \quad 3$

25

253,18

Ilyphagus ilyvestis Hartman 1960

Pherusa abyssalis Fauchald, 1972

18

$33 b$

\section{Fauveliopsidae}

Fauveliopsis rugosa Fauchald, 1972

33

$25 \quad 25 \quad 11$

25

34

12,25

Ampharetidae

Amage sp.

Ampharete acutifrons (Grube, 1860)

Ampharete arctica Malmgren, 1866

$35 \quad 35$

25

Amphicteis scaphobranchiata Moore, 1906

Egamella quadribranchiata Fauchald, 1972

Melinna exilia Fauchald, 1972

$18,19,26$, 35

Melinnampharete eoa Annenkova, 1937

25

25

Mexamage corrugata Fauchald, 1972

$18,25,33$

Paramage scutata Moore, 1923

Samytha sp.

Samythella pala Fauchald, 1972

Schistocomus hiltoni Chamberlin, 1919

Ampharetidae indeterminable

$18,25,28$

$\begin{array}{cccccc}5,6,19,26 & 25 & 20,25,27,34 & 25,34 & 4,13 b, 33 b & 18 \\ & 11 & 5,11, & 25 & 25,26,33 b & 18,25 \\ 5 & & 4 & & 13 b, 34 b & \\ & & & 34 & \end{array}$

11

5,20

4

18

18

18

18

$26,27,33 b$

Terebellidae

Thelepus hamatus Moore, 1905

18 13b, 18, 19, 26, $33 \mathrm{~b}$
25 
TABLE 2 (...continued)

List of polychaete species collected during the four cruises

\begin{tabular}{|c|c|c|c|c|c|c|c|c|}
\hline \multirow[b]{2}{*}{ SPECIES } & \multicolumn{2}{|c|}{ TALUD 4} & \multicolumn{2}{|c|}{ TALUD 5} & \multicolumn{2}{|c|}{ TALUD 6} & \multicolumn{2}{|c|}{ TALUD 7} \\
\hline & $\mathrm{KD}$ & BS & $\mathrm{KD}$ & BS & $\mathrm{KD}$ & BS & $\mathrm{KD}$ & BS \\
\hline Thelepus setosus (Quatrefages, 1865) & 19,25 & & & 11 & & & & 11 \\
\hline Thelepus sp. & & & & & & & & 11 \\
\hline $\begin{array}{l}\text { Streblosoma crassibranchia Treadwell, } \\
1914\end{array}$ & & & 12 & & 20 & & 4 & 25 \\
\hline Trichobranchidae & & & & & & & & \\
\hline Terebellides stroemi Sars, 1835 & $20,25,26$ & & 14 & & 5,20 & & $4,13 b, 26$ & \\
\hline Sabellidae & & & & & & & & \\
\hline Chone gracilis Moore, 1906 & 33 & & & & 34 & & & 18 \\
\hline Pseudopotamilla intermedia Moore, 1905 & & & & & & 34 & & \\
\hline Sabellidae indeterminable & & & & 11 & $18,19,34$ & & & \\
\hline Serpulidae & & & & & & & & \\
\hline Serpulidae indeterminable & & 34 & & & & & & \\
\hline
\end{tabular}

The numbers in columns correspond to the collection stations $(\mathrm{KD}=$ Karling dredge; $\mathrm{BS}=$ Benthic sledge $)$.

(Hartman 1969). One specimen from station 4 (TALUD 6) was found inside a $1.8 \mathrm{~cm}$ long tube with a mucoid base, externally covered by mud. It is probable that the worm abandoned its own tube (a typical chaetopterid tube was found in the same sample) and invaded this empty tube, which may have been produced by another polychaete.

\section{Family Maldanidae}

Maldane cristata. The tubes are thick and mucoid, covered with compact mud $(0.5 \mathrm{~cm}$ external diameter).

Maldanidae sp. 1 to sp. 8. Several maldanids lacked the posterior end which made species identification impossible. According to the characteristics of the prostomium, eight different species were tentatively distinguished.

\section{Family Phyllodocidae}

Eteone cf. dilatae. One specimen fits the description of $E$. dilatae but appears to be a juvenile because the tentacular and dorsal cirri are not well developed. The eyes are absent, while E. dilatae has two small eyes. Although this species has been reported from the intertidal zone to $177 \mathrm{~m}$ (Hartman 1936, 1963, 1968, Reish 1968), our sample was collected at a depth range of 1580 to $1600 \mathrm{~m}$.

Eumida sanguinea. Was found at depths between 2000 and $2100 \mathrm{~m}$. This species has previously been considered cosmopolitan in shelf depths on rocky or mixed sediments (Hartman 1968), from the intertidal zone to 177 m (Rioja 1947, 1962, Hartman 1963, Hernández-Alcántara 1992, Bastida-Zavala 
1993) and had not been previously reported in depths greater than 175 m (Eibye-Jacobsen, pers.comm.).

Steggoa gracilior. This species has been reported for the Gulf of California by Chamberlin (1919b) and Hartman (1968), but depth of occurrence was not provided. The unique specimen found during this study was collected at $1244 \mathrm{~m}$ depth.

\section{Family Polynoidae}

Halosydna johnsoni. It has been reported from the intertidal zone to $531 \mathrm{~m}$, in sand, mud or reefs (Hartman 1939a, 1968, Berkeley and Berkeley 1939, 1941, Rioja 1941, 1962) and amongst basalt boulders (Kudenov 1975a). In this study, this species was found between 1160 and $1230 \mathrm{~m}$ depth.

Polynoidae sp. 1, sp. 2, sp. 3. Three different species of polynoids were recognised but they were too incomplete to make identification possible.

\section{Family Pilargidae}

Ancistrocyllis hartmanae. Two specimens were collected in depths ranging from 1500 to $2040 \mathrm{~m}$, while this species had been reported in the Chesapeake Bay at $12.8 \mathrm{~m}$ by Pettibone (1966) and by Fiege and Bogemann (1999).

\section{Family Amphinomidae}

Pareurythoe (?) sp. Three specimens were found: two from $778-800 \mathrm{~m}$ and one from $1060-1090 \mathrm{~m}$. Placement of these specimens in this genus is dubious since they have slender notoseate, suggesting that all of them are epitokous forms. All specimens have bifid neurosetae, yellow aciculae, three smooth antennae and smooth dorsal cirri, which fits with P. californica, described from the Gulf of California (Hartman 1968). Nevertheless, the presence of dendritic branchiae from setiger three to the end of the body, and the absence of eyes suggests that they could be a different species.
Pseudeurythoe (=Linopherus; SalazarVallejo 1987) ambigua. It was collected at several stations: one specimen from station 14 at 2 080-2 $140 \mathrm{~m}$ (TALUD 5), two specimens from station 18 at 890-950 m (TALUD 6) and one individual from station 18 at $950-1010 \mathrm{~m}$ (TALUD 7). The species is reported from southern California from 1645 to $1900 \mathrm{~m}$ by Hartman (1968). This author indicates that two different branchial arrangements can be found in this species: a) branchiae present at setiger four and continuing for seven segments, and b) branchiae present at setiger three and continuing for 43 segments. The specimens collected at station 18 (both cruises) correspond to the first branchial arrangement, while those from station 14 correspond to the second branchial arrangement, perhaps due to clinal variation.

\section{Family Onuphidae}

Anchinothria fissurata. The tube had not been previously described. In cross section, it consists of a series of transparent hyaline layers with a very hard consistency. It measures about $12 \mathrm{~cm}$ long and $0.5 \mathrm{~cm}$ external diameter. Sometimes, they have attached anemones or serpulid tubes.

\section{Family Eunicidae}

Eunice megabranchia. The specimens were found inside the oscula of sponges and a tube with the specimen was found inside a sponge attached to a tube of the ampharetid Shistocomus hiltoni.

\section{Family Fauveliopsidae}

Fauveliopsis rugosa. Members of the genus Fauveliopsis have been found inside shells of mollusks and tubular tests of foraminifera (Petersen 2000). In the present study, $F$. rugosa was found inside shells of the scaphopods Fissidentalium megathyris and Rhabdus dalli, surrounded by mud. 


\section{Family Ampharetidae}

Paramage scutata. The tube consists of an inner hyaline layer covered with mud, conically shaped, with incrustations of large foraminifera. The animal occupies $1 / 3$ to $1 / 2$ the length of the tube.

Ampharete acutifrons. The tube is a hard mucoid inner layer externally covered with compact mud. It is thick (about $1.5 \mathrm{~cm}$ external diameter) and tapers proximally. The animal occupies about $1 / 7$ of the tube length.

Ampharete arctica. The tube was described by Hartman (1969) as long, tapering proximally, externally covered with fragments of algae, small sticks and debris. Most of the tubes found in the present study are covered with mud, and are similar to those described by Hartman (1969), but specimens were also found in tubes constructed with sand with bands of algae or debris, similar to typical onuphid tubes.

Amphicteis scaphobranchiata. This species builds tubes which are up to $25 \mathrm{~cm}$ long and about $1 \mathrm{~cm}$ external diameter, with a thick mucoid inner layer covered with ring-like compact mud of different colour. The tubes taper proximally and the animal occupies about $1 / 3$ its length.

Egamella quadribranchiata. The tube is thin, made on a mucoid layer covered with bands of mud and fine sand and foraminifera attached to the outer surface. Animals occupy about $1 / 6$ of the tube.

Melinna exilia. The tubes are made of mud, with an external diameter of about $0.3 \mathrm{~cm}$.

Melinnampharete eoa. This species builds tubes that are up to $30 \mathrm{~cm}$ long and about $0.2 \mathrm{~cm}$ external diameter made of fine sand and mud. Animals occupy $1 / 5$ to $1 / 10$ of tube length. M. eoa has been reported in deep-water of the Northwest Pacific (Hartman 1960), thus this is the first record of this species in the Gulf of California.

Mexamage corrugata. This species has a tube about $1 \mathrm{~cm}$ external diameter with a mucoid layer covered with compact mud.

Schistocomus hiltoni. Chamberlin (1919b) described the tube of this species as $3.3 \mathrm{~cm}$ long, with the wall thickened by the adhesion of fine particles of sand, shell fragments, etc. Hartman (1969) described the tube as having a mucoid inner layer, externally covered with sticks set crosswise. The tubes found in the present study are about $15 \mathrm{~cm}$ long and about $1 \mathrm{~cm}$ external diameter, and the animal occupies about 1/10 the length. Some tubes have attached fragments of sponges and foraminifera.

Two species of the ampharetid genera Amage and Samytha have not been reported from the Gulf of California, and their detailed description will be reported elsewhere. Five ovigerous females of Amage sp. were collected at depths between $830-850 \mathrm{~m}$. They differ from the six species previously reported by Hartman (1969) and Fauchald (1972) from the Gulf of California and northeast Pacific. The specimens have 14 thoracic segments, and setigers one to three are asetigerous (as $A$. anops, but different from the other species). They have eleven thoracic segments with notosetae and neuropodial uncini, two pairs of short branchiae (different from A. longibranchiata, which has long branchiae), ten abdominal setigers (as A. scutata and A. sculpta and different from A. delus (=perfecta), A. arieticornuta and $A$. anops), notopodia with notopodial lobes (as $A$. arieticornuta and $A$. anops), and prostomium trilobed (as A. arieticornuta and A. anops and different from $A$. delus and $A$. longibranchiata, which is bifid). The tubes are thick and mudwalled (as $A$. anops and different from $A$. arieticornuta).

Fourteen individuals of Samytha sp. were collected at depths of $850-870 \mathrm{~m}$. They have three pairs of smooth branchiae; 17 thoracic setigers of which 14 are uncinigerous and seven to eight abdominal setigers. The prostomium is trilobed and paleae are absent. The specimens differ from the two species reported from California (Hartman 1969) in the number of abdominal setigers (S. californiensis with 20 and $S$. sexcirrata with 13). The tubes (about $55 \mathrm{~cm}$ long) are covered with mud and have attached anemones and foraminifera. The animal occupies about $1 / 7$ part of the tube. 


\section{DISCUSSION}

Few studies about deep-water polychaetes from the Gulf of California or adjacent areas have been performed, thus results found here are a contribution to their knowledge. This study comprises a list of polychaete taxa collected between 732 and $2250 \mathrm{~m}$ depth, most of them previously collected and described by other authors. Nevertheless, new distribution and depth information is provided. All the species determined at the specific level found in this study have been previously reported for the Gulf of California or adjacent areas except for the pilargid $A$. hartmanae and the ampharetid $M$. eoa, which constitute new distribution records. New depth records are provided for $E$. cf. dilatae, E. sanguinea, S. gracilior, H. johnsoni, A. hartmanae, and P. ambigua.

In order to facilitate further taxonomic studies, the descriptions of the tubes or other protective structures, which had not been previously mentioned in the literature are provided for M. cristata, A. fissurata, E. megabranchia, P. scutata, A. acutifrons, A. scaphobranchiata, E. quadribranchiata, M. exilia, M. eoa, and $M$. corrugata This study also includes new descriptions of the tubes of $P$. limicolus, $F$. rugosa, A. arctica, and $S$. hiltoni, which differ from previous descriptions.

The descriptions of ampharetids belonging to the genera Amage and Samytha and comparisons with species reported from adjacent areas suggest that they are probably undescribed species.

Based on the number of taxa found during this study, the Karling dredge was more effective than the benthic sledge for collecting polychaetes inhabiting soft bottom, since it is able to collect species representing both, infauna and epifauna, while the benthic sledge only collects mostly large specimens from the epifauna. Moreover, the smaller mesh used for sieving sediments collected with the Karling dredge allowed the capture of smaller animals.

\section{ACKNOWLEDGMENTS}

This study is part of the project CONACyT number $31805-\mathrm{N}$ with support from PAPIITIN217306-3. I want to thank Michel Hendrickx, director of the projects, for his advice and review of the manuscript. Collection of samples was performed thanks to the crew members of the R/V "El Puma", students and technical staff from the Mazatlan Marine Station (Instituto de Ciencias del Mar y Limnología, UNAM). I am especially grateful to Arturo Toledano, José Salgado, Héctor Nava, Benjamín Yáñez, Ernesto Sánchez and Alejandro Nava for their help during sampling. Thanks are also given to Leslie Harris, Kristian Fauchald, Sergio Salazar and Luis Carrera for their help in identification of dubious polychaete specimens. Arturo Toledano identified the scaphopods $F$. megathyris and $R$. dalli.

\section{RESUMEN}

Se recolectaron anélidos poliquetos de fondos profundos del SE del golfo de California durante cuatro campañas oceanográficas entre 2000 y 2001. El muestreo de organismos bentónicos se llevó a cabo mediante una draga de arrastre bentónica para recolectar epifauna y una draga tipo Karling para epifauna y endofauna, en un intervalo de profundidad de 732 a $2250 \mathrm{~m}$. Se presenta un listado de poliquetos con su distribución dentro del área de estudio. En total se identificaron 73 especies (distribuidas en 33 familias). Además, 11 especies fueron identificadas a nivel genérico y 20 a nivel de familia. Con excepción de Ancistrosyllis hartmanae y Melinnampharete eoa, todas las especies habían sido registradas en fondos blandos del golfo de California o zonas adyacentes. Se proporciona nueva información sobre los intervalos de profundidad, la distribución geográfica, la morfología y la descripción de tubos donde los organismos fueron encontrados. Las características morfológicas de Amage sp. y Samytha sp. no coinciden con las especies de estos géneros registradas en el golfo de California, lo que sugiere que podría tratarse de especies no descritas.

Palabras clave: poliquetos, océano profundo, tubos de poliquetos, distribución batimétrica, sureste del Golfo de California, México. 


\section{REFERENCES}

Alvarez-Borrego, S. \& R.A. Schwartzlose. 1979. Masas de agua del Golfo de California. Cienc. Mar. 6: 43-63.

Bastida-Zavala, J.R. 1993. Taxonomía y composición biogeográfica de los poliquetos (Annelida: Polychaeta) de la bahía de La Paz, B.C.S., México. Rev. Inv. Cient. 4: 11-39.

Berkeley, E. \& C. Berkeley. 1939. On a collection of Polychaeta, chiefly from the West Coast of Mexico. Ann. Mag. N. Hist. Ser. 11. 3: 321-346.

Berkeley, E. \& C. Berkeley. 1941. On a collection of Polychaeta from Southern California. Bull. So. Calif. Acad. Sci. 40: 16-59.

Blake, J.A. 1985. Polychaeta from the vicinity of deepsea geothermal vents in the eastern Pacific I: Euphrosinidae, Phyllodocidae, Hesionidae, Nereidae, Glyceridae, Dorvilleidae, Orbiniidae, and Maldanidae. Bull. Biol. Soc. Wash. 6: 67-101.

Blake, J.A. \& B. Hilbig. 1990. Polychaeta from the vicinity of deep-sea hydrothermal vents in the eastern Pacific. II: New species and records from the Juan de Fuca and Explorer ridge systems. Pac. Sci. 44: 219-253.

Blake, J.A (ed.). 1994-2000. Taxonomic Atlas of the benthic fauna of the Santa Maria Basin and Western Santa Barbara Channel. Volumes 4-7. Santa Barbara Museum of Natural History, Santa Barbara, California, USA.

Chamberlin, R.V. 1919a. The Annelida Polychaeta. Harvard Mus. Comp. Zool., Mem. 48: 1-514.

Chamberlin, R.V. 1919b. New polychaetous annelids from Laguna Beach, California. J. Ent. \& Zool. 11: 1-23.

Diaz, R.J. \& R. Rosenberg. 1995. Marine benthic hypoxia: a review of its ecological effects and the behavioural responses of benthic macrofauna. Oceanogr. \& Mar. Biol.: An Annual Rev. 33: 245-303.

Fauchald, K. 1968. Onuphidae (Polychaeta) from Western Mexico. Allan Hancock Monogr. Mar. Biol. 3: 1-82.

Fauchald, K. 1970. Polychaetous annelids of the families Eunicidae, Lumbrineridae, Iphitimidae, Arabellidae, Lysaretidae and Dorvilleidae from western Mexico. Allan Hancock Monogr. Mar. Biol. 5: 1-335.

Fauchald, K. 1972. Benthic polychaetous annelids from deep water off western Mexico and adjacent areas in the Eastern Pacific Ocean. Allan Hancock Monogr. Mar. Biol. 7: 1-575.

Fauchald, K. 1977. The polychaete worms. Definitions and keys to the orders, families and genera. Nat. Hist.
Mus. of Los Angeles County, and Allan Hancock Found. Science Ser. 8: 1-188.

Fauchald, K. \& D.R. Hancock. 1981. Deep-water polychaetes from a transect off central Oregon. Allan Hancock Found. Monogr. Mar. Biol. 11: 1-73.

Fiege, D. \& M. Boggemann. 1999. Ancistrosyllis fioronii, a new species of Pilargidae from the North Sea, with a key and synoptic table of characters for all species of the genus Ancistrosyllis McIntosh 1879 (Annelida, Polychaeta, Pilargidae). Senckenb. Biol. 78: 135-140

Hartman, O. 1936. A review of the Phyllodocidae (Annelida Polychaeta) of the coast of California, with descriptions of nine new species. Univ. Calif. Publ. Zool. 41: 117-132.

Hartman, O. 1938. Descriptions of new species and new generic records of Polychaetous annelids from California of the families Glyceridae, Eunicidae, Stauronereidae, and Opheliidae. Univ. Calif. Publ. Zool. 43: 93-111.

Hartman, O. 1939a. Polychaetous annelids. Allan Hancock Pac. Exped. 7: 1-156.

Hartman, O. 1939b. New species of polychaetous annelids from Southern California. Allan Hancock Pac. Exped. 7: 157-172.

Hartman, O. 1944a. Polychaetous annelids. Allan Hancock Pac. Exped. 10: 1-237.

Hartman, O. 1944b. Polychaetous annelids from California, including the descriptions of two new genera and nine new species. Allan Hancock Pac. Exped. 10: 239-307.

Hartman, O. 1944c. Polychaetous annelids. Allan Hancock Pac. Exped.10: 311-389.

Hartman, O. 1951. Literature of the polychaetous annelids. Allan Hancock Found, University of Southern California, Los Angeles, California, USA. p. 1-290.

Hartman, O. 1955. Quantitative survey of the benthos of San Pedro Basin, southern California. Allan Hancock Pac. Exped. 19: 1-185.

Hartman, O. 1957. Orbiniidae, Apistobranchidae, Paraonidae and Longosomidae. Allan Hancock Pac. Exped. 15: 207-393.

Hartman, O. 1960. Systematic account of some marine invertebrate animals from the deep Basins off southern California. Allan Hancock Pac. Exped. 22: 69215 .

Hartman, O. 1961. Polychaetous annelids from California. Allan Hancock Pac. Exped. 25: 1-226. 
Hartman, O. 1963. Submarine canyons of southern California Polychaetous annelids. Allan Hancock Pac. Exped. 27: 1-93.

Hartman, O. 1966. Quantitative survey of the benthos of San Pedro Basin, Southern California. Allan Hancock Pac. Exped.19: 187-456.

Hartman, O. 1968. Atlas of errantiate polychaetous annelids from California. Allan Hancock Found, University of Southern California, Los Angeles, California, USA. $828 \mathrm{p}$.

Hartman, O. 1969. Atlas of sedentariate polychaetous annelids from California. Allan Hancock Found. University of Southern California, Los Angeles, California, USA. 812 p.

Hernández-Alcántara, P. 1992. Los poliquetos (Annelida: Polychaeta) de la plataforma continental del Golfo de California, México. Taxonomía, Abundancia numérica y distribución geográfica. Tesis de Maestría, UNAM, México D.F., México. 427 p.

Hernández-Alcántara， P. \& V. Solís-Weiss. 1999 Systematics and distribution of the polychaetes (Annelida: Polychaeta) from the sublittoral zone in the Gulf of California. Oceánides 13, 14: 25-38.

Kudenov, J.D. 1975a. Errant polychaetes from the Gulf of California, Mexico. J. Nat. Hist. London 9: 65-91

Kudenov, J.D. 1975b. Sedentary polychaetes from the Gulf of California, Mexico. J. Nat. Hist. London 9: 205-231.

Kudenov, J.D. 1980. Annelida: Polychaeta (Bristleworms), p. 77-123. In R. Brusca (ed.). Common intertidal invertebrates of the Gulf of California, University of Arizona. Tucson, Arizona, USA.

Lezcano-Bustamante, B.G. 1989. Estudio prospectivo de la distribución, diversidad y abundancia de las poblaciones de anélidos poliquetos en la porción sur del golfo de California. Tesis Profesional, UNAM, Mexico D.F., Mexico. 98 p.

Parker, R.H. 1964. Zoogeography and ecology of some macro-invertebrates particularly mollusks, in the Gulf of California and the continental slope off Mexico. Vidensk. Medd. Fra Dansk Naturh. 126: 1-178.

Paxton, H. 1986. Generic revision and relationships of the family Onuphidae (Annelida: Polychaeta). Rec. Aus. Mus. 38: 1-74.

Petersen, M.E. 2000. A new genus of Fauveliopsidae (Annelida: Polychaeta), with a review of its species and description of some described taxa. Bull. Mar. Sci. 67: 491-515.

Pettibone, M.H. 1966. Revision of the Pilargidae (Annelida: Polychaeta) including descriptions of new species, and redescription of the pelagic Podarmus ploa Chamberlin (Polynoidae). Proc. U.S. Nat. Mus. 118: 155-208.

Reish, D.J. 1968. A biological survey of Bahia de los Angeles, Gulf of California, Mexico. Trans. San Diego Soc. Nat. Hist. 15: 67-106.

Rioja, E. 1941. Estudios Anelidológicos. An. Inst. Biol. Mex. 12: 669-746.

Rioja, E. 1947. Estudios Anelidológicos. An. Inst. Biol. Mex. 18: 198-224.

Rioja, E. 1962. Estudios Anelidológicos. An. Inst. Biol. Mex. 33: 131-229.

Rosenberg, R., B. Hellman \& B. Johansson. 1991. Hypoxic tolerance on marine benthic fauna. Mar. Ecol. Progr. Ser. 79: 127-131.

Salazar-Vallejo, S.I. 1987. A new amphinomid polychaete (Annelida: Polychaeta) from Western Mexico. Rev. Biol. Trop. 35: 77-82.

Salazar-Vallejo, S.I., J.A. de León-González \& H. SalaicesPolanco. 1989. Poliquetos (Annelida: Polychaeta) de México. Libros Universitarios, Universidad Autónoma de Baja California Sur. La Paz, Mexico. 212 p.

Sarti-Martínez, A.L. 1984. Estudio prospectivo de la distribución, abundancia y diversidad de los anélidos poliquetos de la zona norte del golfo de California. Tesis Profesional, UNAM, Mexico D.F., Mexico. 53 p.

Solís-Weiss, V. \& B. Hilbig. 1992. Redescription of Ophryotrocha platykephale Blake (Polychaeta, Dorvilleidae) from the Guaymas Basin hydrothermal vents. Bull. Southern Calif. Acad. Sci. 91: 92-96.

Solís-Weiss, V. \& P. Hernández-Alcántara. 1994. Amphisamytha fauchaldi: a new species of Ampharetid (Annelida: Polychaeta) from the hydrothermal vents at Guaymas Basin, Mexico. Bull. Southern Calif. Acad. Sci. 93: 127-134.

Treadwell, A.L. 1923. Polychaetous annelids from lower California with descriptions of new species. Amer. Mus. Novitat. 74: 1-11.

Williams, S.J. 1987. Taxonomic notes on some Ampharetidae (Polychaeta) from Southern California. Bull. Biol. Soc. Wash. 7: 251-258. 
